\begin{tabular}{l}
\hline MATAPPA: Jurnal Pengabdian Kepada Masyarakat \\
Volume 1 | Nomor 2 | September |2018 \\
e-ISSN: 2614-6673 dan p-ISSN: $2615-5273$ \\
\begin{tabular}{|l|l|} 
(c) (1) This work is licensed under a Creative Commons Attribution \\
4.0 International License
\end{tabular}
\end{tabular}

\title{
Pemberdayaan Anak Pemulung Melalui Teknik Storytelling
}

\author{
Farida Aryani ${ }^{1}$, Muhammad Rais ${ }^{2}$
}

\author{
Keywords : \\ Storytelling; \\ Anak Pemulung.

\section{Corespondensi Author \\ ${ }^{1)}$ Fakultas Ilmu Pendidikan \\ Universitas Negeri Makassar \\ Email: farida.aryani@unm.ac.id \\ ${ }^{2)}$ Fakultas Teknik Universitas \\ Negeri Makassar \\ Email: raismisi@gmail.com}

\section{History Artikel}

Received: 11-06-2018

Reviewed: 20-06-2018

Revised: 15-07-2018

Accepted: 09-07-2018

Published: 28-07-2018

\begin{abstract}
Abstrak. Pemberian storytelling ini diharapkan dapat membatu meningkatkan kemampuan sosial yakni: 1) kemampuan berkomunikasi, yaitu, kemapuan untuk bercerita dan berimajinasi, kemampuan menggunakan bahasa tubuh yang tepat, mengucapkan salam, memperkenalkan diri, menjawab pertanyaan, dan kemampuan bertanya; 2) kemampuan menjalin persahabatan, yaitu menjalin pertemanan, mengucapkan dan menerima ucapan terima kasih, memberikan dan menerima pujian, terlibat dalam aktifitas bersama, berinisiatif melakukan kegiatan dengan orang lain, meminta dan memberikan pertolongan; 3) kemampuan dalam menghadapi situasi sulit, yaitu memberikan kritik dan menerima penolakan, bertahan dalam tekanan kelompok dan minta maaf. Melalui IbM ini pemberdayaan anak pemulung Kecamatan Manggala Kelurahan Tamangapa melalui storytelling dengan fokus kepada kemampuan berkomunikasi, kemampuan menjalin persahabatan dan kemampuan menghadapi situasi. Seluruh tujuan, target dan metode ini dirancang dalam skenario yang terukur, dimulai dari analisis kondisi masyarakat mitra, merancang program storytelling dengan melibatkan anak-anak pemulung di TPAS diselenggarakan dalam waktu 2 bulan, sehingga meningkatkan kemampuan sosial anak-anak pemulung. Hasil kegiatan PKM bagi anak pemulung menunjukkan kemampuan 1) berkomunikasi, bercerita dan berimajinasi, menggunakan bahasa tubuh yang tepat dan memberikan respon dan menanggapi cerita; 2) menjalin persahabatan dengan teman sebaya; 3) menghadapi situasi sulit dalam kesehariannya.
\end{abstract}

\section{PENDAHULUAN}

Saat ini komunitas pemulung yang bermukim apa bila di klasifikasi usia, komunitas pemulung dibagi dua kelurahan di kota Makassar ini melakukan menjadi; pemulung remaja yang berusia 19-33 aktifitas mereka di Tempat Pembuangan Akhir tahun berjumlah 199 orang; laki-laki berjumlah Sampah (TPAS) Tamangapa, Kecamatan 122 orang dan perempuan berjumlah 77 orang. Manggala Kota Makassar. Mereka berasal dari Kelompok umur 6-18 tahun berjumlah 514; laki- latar belakang etnis yang berbeda, yaitu; etnis Bugis, Kajang dan Makassar yang berasal dari kemudian menjadi landasan analisis dalam Kabupaten Sinjai, Jeneponto, Takalar, Maros, paper ini. Pemikiran Sztompka dan beberapa Bantaeng, Bulukumba, Gowa dan Kota Makassar. (Simmau, 2013) 
Setelah melakukan aktivitas memulung dilanjutkan pada pekerjaan sebagai buruh kasar/bangunan dan lain-lain. Ini merupakan akibat dari pengaruh dan tuntutan arus modernisasi dan globalisasi, yang memaksa dan memberikan kesadaran untuk menjadikan masyarakat pemulung ikut dalam pergulatan dan menjadi korban pengaruh dari arus modernisasi dan globalisasi. Dari hal tersebut, maka tidak sedikit di antara mereka menjadikan memulung sebagai pekerjaan utamanya (pokok) dan mengikutsertakan kaum kerabat terdekat dari tanah kelahiran (kampung halaman) yang rela meninggalkan pekerjaan sebagai buruh tani atau bangunan menuju ke Kota Makassar hanya untuk bekerja sebagai seorang pemulung.

Berpikir materialistis dan individualis menjadikan sikap seseorang pada pekerjaan tertentu, yang mana lebih mementingkan pekerjaan yang menghasilkan materi yang banyak tanpa memperhatikan hubungan sosial dan norma-norma yang berlaku di masyarakat sekitar dalam melakukan pekerjaan tersebut. Banyak diantaranya yang putus sekolah dan enggan untuk bersekolah kembali karena situasi maupun masalalah yang dihadapi anak pemulung khususnya untuk berinteraksi dengan masyarakat dan disekolahnya. Pola pikir untuk berpendidikan relatif rendah disebabkan oleh terpenuhinya segala kebutuhan materi tanpa perlu menempuh jenjang pendidikan, sehingga gaya hidup yang menjadi kepribadian adalah, gaya hidup individualis, konsumerisme dan hedonisme berlebihan.

Storytelling yang berarti penyampaian cerita kepada para pendengar dirasa tepat dijadikan metode pembelajaran bagi anak karena sifatnya yang menyenangkan, tidak menggurui, serta dapat mengembangkan imajinasi (Majid, 2008; Yudha, 2007). Cerita yang disajikan melalui storytelling akan mengisi memory anak dengan berbagai informasi termasuk nilai-nilai kehidupan dan berbagai sudut pandang. Peristiwa-peristiwa yang ada dalam cerita akan memperkaya pengalaman anak sehingga dapat digunakan sebagai bahan referensi pemecahan masalah atau mengubah perilaku (Burns, 2005). Anggraeni (2009) menyatakan bahwa terdapat penurunan perilaku agresif pada anak setelah dilakukan pemberian dongeng bertema prososial.

Pemberian story telling ini diharapkan dapat membatu meningkatkan kemampuan sosial yakni: 1) kemampuan berkomunikasi, yaitu, kemapuan untuk bercerita dan berimajinasi, kemampuan menggunakan bahasa tubuh yang tepat, mengucapkan salam, memperkenalkan diri, menjawab pertanyaan, dan kemampuan bertanya; 2) kemampuan menjalin persahabatan, yaitu menjalin pertemanan, mengucapkan dan menerima ucapan terima kasih, memberikan dan menerima pujian, terlibat dalam aktifitas bersama, berinisiatif melakukan kegiatan dengan orang lain, meminta dan memberikan pertolongan; 3) kemampuan dalam menghadapi situasi sulit, yaitu memberikan kritik dan menerima penolakan, bertahan dalam tekanan kelompok dan minta maaf (MqQuaid, 2000). Melalui IbM ini pemberdayaan anak pemulung Kecamatan Manggala Kelurahan Tamangapa melalui storytelling dengan fokus kepada kemampuan berkomunikasi, kemampuan menjalin persahabatan dan kemampuan menghadapi situasi.

\section{METODE}

Metode yang digunakan dalam kegiatan pengabdian ini berupa kegiatan eksperimen dengan melakukan kegiatan storytelling pada anak pemulung TPAS Tamangapa. Secara umum langkah-langkah yang telah dilaksanakan mulai dari melakukan persiapan, pelaksanaan, evaluasi dan refleksi. Kegiatan storytelling diawali dengan pemberian materi yang berkaitan dengan kemampuan keterampilan sosial dimulai dari pengantar dan penjelasan tentang cara menemukan dan meningkatkan kemampuan sosial yang dilengkapi dengan praktek dan simulasi tentang mengenal karakter anak. Setelah pemberian materi setiap anak diberikan pelatihan bercerita dan berimajinasi di depan kelompoknya, sehingga setiap anak mampu untuk melakukan storytelling.

\section{HASIL DAN PEMBAHASAN}

Hasil kegiatan PKM ini meliputi: (1) meningkatnya kemampuan berkomunikasi anak pemulung, yaitu kemampuan untuk memberikan respond dan menanggapi cerita, kemampuan menyampaikan bercerita kembali dan berimajinasi, kemampuan menggunakan bahasa tubuh yang tepat, mengucapkan salam, memperkenalkan diri; (2) meningkatnya kemampuan menjalin persahabatan dengan teman sebaya, seperti kebiasaan mengucapkan dan menerima ucapan terima kasih, memberikan 
dan menerima pujian, dan mampu bekerja sama dan terlibat dalam aktifitas positif bersama; (3) meningkatkan kemampuan dalam menghadapi situasi sulit seperti memberikan kritik dan menerima penolakan, serta mampu menghadapi konflik dalam kelompok.

Berikut adalah dokumentasi pada saat pelatihan:

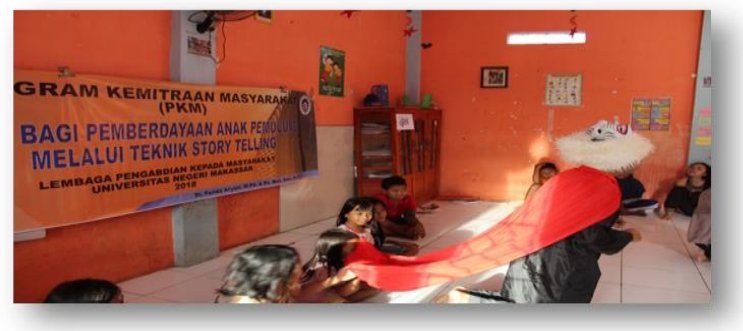

Gambar 1 Pengenalan cara menyampaikan cerita kepada anak pemulung

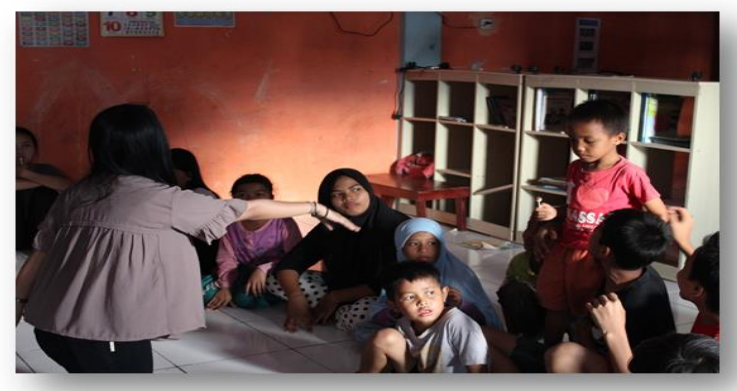

Gambar 2 Melatih anak pemulung untuk mengemukakan pendapat

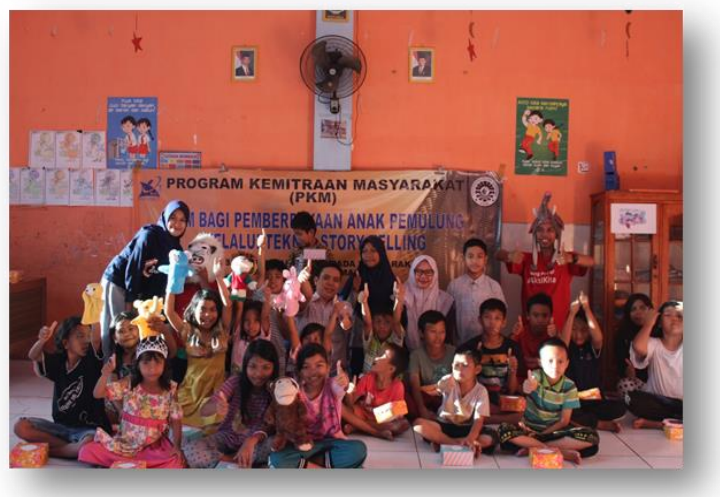

Gambar 4 Foto Bersama Anak Pemulung dengan Tim Pengabdian

Dari gambar diatas terlihat peserta antusias mengikuti kegiatan storytelling. Sebelum diberikan storytelling anak pemulung mendapatkan materi mengenai kemampuan keterampilan sosial meliputi (1) keterampilan berkomunikasi (2) keterampilan bekerja sama (3) keterampilan menghadapi konflik serta (4) keterampilan storytelling. Kegiatan ini diberikan dengan metode yang bervariatif dan menyenangkan, sehingga selama proses kegiatan ini anak pemulung sangat antuasis mengikutinya. Kegiatan ini diikuti oleh 20 anak yang berasal dari sekitar TPAS Tamangapa.

Materi pertama yaitu membahas tentang keterampilan berkomunikasi. Keterampilan berkomunikasi yang dibahas dalam kegiatan ini adalah kemampuan anak dalam menyampaikan dan menerima pesan sehingga tujuan pesan tersebut dapat diterima dengan baik. Anak pemulung perlu mengetahui tentang keterampilan komunikasi agar mereka mampu untuk bersosialisasi dengan baik dalam kesehariannya. Anak dikatakan memiliki keterampilan berkomunikasi jika orang tersebut mampu menyampaikan ide, pikiran, serta pendapatnya dengan baik dan jelas, sehingga berani untuk berbicara di depan umum tanpa rasa takut salah ataupun ditolak, mampu mengemukakan pendapat dengan jelas, mampu menanggapi dengan baik dan bersosialisasi dengan baik dalam kehidupan sehari-harinya. Pada materi ini ditekankan juga bahwa keterampilan komunikasi adalah hal yang penting untuk dimiliki dalam bersosialisasi karena tanpa kemampuan komunikasi ini anak akan mengalami kesulitan dalam bergaul. Kesalahan dalam berkomunikasi akan menimbulkan konflik atau kesalapahaman dengan teman sebaya. Keterampilan berkomunikasi ini juga dilatih dalam setiap pertemuan kegiatan storytelling ini, anak pemulung yang telah mendengarkan cerita diminta pendapatnya serta kesan yang mereka dapatkan dalam pertemuan ini.

Materi selanjutnya adalah tentang kemampuan bekerja sama. Bekerja sama yang dimaksudkan dalam materi ini adalah keterampilan anak dalam bekerja secara berkelompok, menjalin persabatan dengan teman sebaya. Bekerja secara berkelompok akan melatih anak dalam mengucapkan dan menerima ucapan terima kasih, saling memberi dan meneri pujian, berinisiatif dalam melakukan kegiatan dengan teman sebayanya serta saling tolong menolong. Meski terdengar sepeleh namun kegiatan-kegiatan tersebut jika dibiasakan dalam keseharian akan memudahkan anak-anak dalam bekerja secara berkelompok. Anak pemulung mayoritas melakukan aktivitas memulung sampah sendirian atau bersama keluarganya, seharian memulung membuat waktu untuk bermain bersama teman sebayanya lebih sedikit sehingga hal ini berdampak pada mudahnya 
timbul konflik antar pemulung meski hanya persoalan kecil.

Kegiatan ini juga dilengkapi dengan beberapa ice breaking yang diberikan setiap sebelum memulai kegiatan. Ice breaking yang diberikan adalah permainan-permainan yang akan melatih kemampuan bekerjasama setiap anak. Melalui kegiatan yang menyenangkan anak akan lebih mudah untuk terlibat dalam satu aktifitas berkelompok. Kerjasama yang positif akan menimbulkan kebiasaan positif pula, manfaat bekerja sama dalam kegiatan ini agar adanya persaingan yang baik antar setiap anak, memotivasi setiap anak melakukan aktifitas yang lebih baik lagi, lebih produktif dan bersemangat, serta mempererat hubungan persaudaraan.

Materi selanjutnya tentang keterampilan menghadapi konflik. Hidup dalam kondisi lingkungan keluarga menengah kebawah dan pendidikan yang rendah dapat menimbulkan konflik. Agar anak-anak pemulung dapat menjalani kesehariannya dengan baik maka mereka dituntut untuk memiliki keterampilan dalam menghadapi konflik. Konflik yang dimaksudkan disini adalah kesalahpahaman yang kemungkinan sering dialami sesama anak pemulung. Kegiatan storytelling yang dilakukan dalam suasana yang menyenangkan dan dilakukan secara berkelompok melatih anak dalam memberikan komentar dan menerima penolakan, bertahan dalam tekanan kelompok serta membiasakan diri untuk meminta maaf saat melakukan kesalahan.

Setelah menerima materi mengenai kemampuan keterampilan sosial anak pemulung diberikan latihan melakukan storytelling. Diawal pertemuan anak-anak melihat penampilan storytelling dari kakak-kakak pendamping di yayasan, setelah itu anak pemulung diajarkan teknik untuk melakukan storytelling dengan harapan selanjutnya mereka yang akan berbagi cerita dan keceriaan dengan teman-temannya.

\section{SIMPULAN DAN SARAN}

Kesimpulan dari kegiatan pengabdian ini adalah: (1) meningkatnya kemampuan berkomunikasi anak pemulung, yaitu kemampuan untuk memberikan respond dan menanggapi cerita, kemampuan menyampaikan bercerita kembali dan berimajinasi, kemampuan menggunakan bahasa tubuh yang tepat, mengucapkan salam, memperkenalkan diri. (2) meningkatnya kemampuan menjalin persahabatan dengan teman sebaya, seperti kebiasaan mengucapkan dan menerima ucapan terima kasih, memberikan dan menerima pujian, dan mampu bekerja sama dan terlibat dalam aktifitas positif bersama, dan (3) meningkatkan kemampuan dalam menghadapi situasi sulit seperti memberikan kritik dan menerima penolakan, serta mampu menghadapi konflik dalam kelompok.

\section{DAFTAR RUJUKAN}

Anggraeni, A. (2009). Pengaruh Pemberian Dongeng Bertema Prososial Terhadap Penurunan Perilaku Agresif Anak. (Abstrak).

Burns, G.W. (2005). 101 Healing Stories for Kids and Teen: Using Metaphors in Therapy. New York: John Wiley and Sons, Inc.

Simmau, S. (2013). Perubahan Sosial pada Komunitas Pemulung di TPAS Antang Tamangapa Kota Makassar. Socius, XIV, 64-70.

Majid, A.A.A. (2008). Mendidikan dengan Cerita. Bandung: Rosda.

MqQuaid. (2000). Development of an integrated cognitive-bahavior and social skill training intervention for older patients with schizoprenia. The Journal of Psychotherapy Practise and Research, 9(3), 149-156

Yudha, A.A. (2007). Cara Pintar Mendongeng. Bandung: Mizan. 